\title{
Measurements of Soil and Canopy Exchange Rates in the Amazon Rain Forest using $222 \mathrm{Rn}$
}

\author{
S.E. Trumbori:,1,2 M. Kel.ler, i, S.C. Worsy,5 and J.M. da COSTAn
}

\begin{abstract}
Measurements of the emission of ${ }^{222} \mathrm{Rn}$ from Amazon forest soils, and profiles of ${ }^{222} \mathrm{Rn}$ in air were used to study the ventilation of the soil atmosphere and the noctumal forest canopy. The emission of ${ }^{222} \mathrm{Rn}$ from the yellow clay soils dominant in the study area averaged $0.38 \pm 0.07$ atom $\mathrm{cm}^{-2} \mathrm{~s}^{-1}$. Nearby sand soils had similar fluxes, averaging $0.30 \pm 0.07$ atom $\mathrm{cm}^{-2} \mathrm{~s}^{-1}$. The effective diffusivity in the clay soil $\left(0.008 \pm 0.004 \mathrm{~cm}^{2} \mathrm{~s}^{-1}\right)$, was lower than that for the sand soil $\left(0.033 \pm 0.030 \mathrm{~cm}^{2} \mathrm{~s}^{-1}\right)$. Profiles of ${ }^{222} \mathrm{Rn}$ and $\mathrm{CO}_{2}$ in air showed steepest concentration gradients in the layer between 0 and $3 \mathrm{~m}$ above the soil surface. Aerodynamic resistances calculated for this layer from ${ }^{222} \mathrm{Rn}$ and $\mathrm{CO}_{2}$ varied from 1.6 to $18 \mathrm{~s} \mathrm{~cm}^{-1}$, with greater resistance during the aftemoon than at night. Time averaged profiles of ${ }^{222} \mathrm{Rn}$ in the forest canopy measured during the evening and night were combined with the soil flux measurements to compute the resistance of the subcanopy to exchange with overlying air. The integrated nocturnal rate of gas exchange between the canopy layer $(0$ to $41 \mathrm{~m})$ and overlying atmosphere based on ${ }^{222} \mathrm{Rn}$ averaged $0.33 \pm 0.15 \mathrm{~cm} \mathrm{~s}^{-1}$. An independent estimate of gas exchange, based on 13 nights of $\mathrm{CO}_{2}$ profiles, averaged $0.21 \pm 0.40 \mathrm{~cm} \mathrm{~s}^{-1}$. These exchange rates correspond to flushing times for the $41 \mathrm{~m}$ canopy layer of 3.4 and 5.5 hours, respectively. Comparison of ${ }^{222} \mathrm{Rn}$ and $\mathrm{CO}_{2}$ profiles show that the nocturnal production of $\mathrm{CO}_{2}$ by above-ground vegetation was about $20 \%$ of the soil emission source, consistent with data from eddy-correlation experiments (Fan et al., this issue).
\end{abstract}

\section{INTRODUCTION}

The soils and vegetation of tropical forests are important sources of atmospheric trace gases such as nitric oxide, carbon monoxide, and isoprene [Kaplan et al., 1988; Rasmussen and Khalil, 1988; Zimmerman et al., 1988; Bakwin et al., this issue (a); Jacob and Wofsy, this issue]. Soil and vegetation surfaces act as sinks for ozone, nitrogen dioxide, and other reactive gases [Fan et al., this issue; Bakwin et al., this issue (b); Jacob and Wofsy, this issue). Together this ensemble of sources and sinks determines the chemistry of the troposphere over the forest.

\footnotetext{
${ }^{1}$ Department of Geological Sciences, Columbia University, and Lamont-Doherty Geological Observatory, Palisades, New York.

${ }^{2}$ Now at Lawrence Livermore National Laboratory, Livermore, California.

${ }^{3}$ Department of Geology, Princeton University, Princeton, New Jersey.

${ }^{4}$ Now at National Center for Atmospheric Research, Boulder, Colorado.

${ }^{5}$ Earth and Planetary Sciences, Division of Applied Sciences,

Harvard University, Cambridge, Massachusetts.

${ }^{6}$ Universidad Federal de Vicosa, Departament Engenharea Agricola, Minas Gerais, Brazil.
}

Copyright 1990 by the American Geophysical Union.

Paper number 90JD00772.

0148-0227/90/90JD-00772\$05.00
Production and destruction of these gas species in the forest canopy layer are mediated by biological processes and chemical reactions within the layer and by the rate of exchange between the canopy layer and the overlying atmosphere. In order to study the chemistry of the atmosphere over a tropical forest, we must quantify the rates of exchange of air between the canopy layer and the overlying atmosphere.

The rate of gas exchange may be represented by an exchange coefficient $k\left(\mathrm{~cm} \mathrm{~s}^{-1}\right)$, which relates the inventory of a trace gas in the air beneath the forest canopy to soil flux $S$, and production $P$, and loss $L$ within the canopy layer,

$$
h \frac{d C}{d t}=\int_{0}^{h}[P-L] d z+S-k\left[\bar{C}-C_{t}\right]
$$

where $h$ is the canopy height, taken as $41 \mathrm{~m}$. The flux between the subcanopy layer and the overlying atmosphere is given by the last term on the right, where $\bar{C}$ and $C_{t}$ denote the mean concentration in the canopy and atmosphere above the forest, respectively.

The rate of gas exchange, denoted $k$ in (1), may also be expressed as a resistance to gas transfer, $R(=1 / k)$. Aerodynamic resistances are useful for comparison with stomatal resistances when studying the uptake of gases by plants [e.g., Fan et al., this issue]. The residence time of air in the canopy layer with respect to ventilation by overlying air is obtained from $R$ times the layer thickness.

We use ${ }^{222} \mathrm{Rn}$, a radioactive noble gas produced by the alpha decay of ${ }^{226} \mathrm{Ra}$ in rocks and soils, as an inert 
tracer of ventilation of the forest canopy layer at night. Because ${ }^{222} \mathrm{Rn}$ originates in the soil and is inert, its concentration in the canopy layer may be related directly to the canopy ventilation rate if the soil flux is known. The half-life for alpha decay of ${ }^{222} \mathrm{Rn}$ is 3.8 days, a useful time scale for determining rates of soil-atmosphere gas exchange [Tanner, 1964; Clements and Wilkening, 1974; Dörr and Münnich, 1987]. Rates of gas exchange between the canopy layer and the overlying atmosphere are rapid enough for ${ }^{222} \mathrm{Rn}$ to be considered a conservative tracer in the canopy layer.

We carried out a program of ${ }^{222} \mathrm{Rn}$ measurements during the Amazon Boundary Layer Experiment (ABLE 2B) project in the central Amazon forest in order to quantify the rates of gas exchange between the air in the canopy layer and the overlying atmosphere. We determined emissions of ${ }^{222} \mathrm{Rn}$ from the soil using a chamber technique. Gas exchange rates above and below the soil surface were calculated by comparison of these fluxes with profiles of ${ }^{222} \mathrm{Rn}$ from the soil atmosphere and from the subcanopy layer between 0 and $41 \mathrm{~m}$. We emphasized nighttime gas exchange because daytime exchange is more rapid, and therefore more difficult to study using ${ }^{222} \mathrm{Rn}$ as a tracer. We also compared ${ }^{222} \mathrm{Rn}$ profiles to $\mathrm{CO}_{2}$ profiles in order to estimate the contribution of respiration by above-ground vegetation to nocturnal $\mathrm{CO}_{2}$ production. Profiles of $\mathrm{CO}_{2}$ concentration were then used to calculate an estimate of nocturnal canopy-atmosphere gas exchange over an extended temporal range.

\section{SAMPLING SITE}

Soil emission rates of ${ }^{222} \mathrm{Rn}$, and measurements of ${ }^{222} \mathrm{Rn}$ in soil atmosphere and air, were made in terra firme forest during the rainy season at four sites in Reserva Adolfo Ducke near Manaus, Brazil. The height of the forest canopy at the Ducke site is approximately $30 \mathrm{~m}$, with emergent trees reaching $35 \mathrm{~m}$. A scaffolding tower extending to $41 \mathrm{~m}$ provided a sampling platform for air throughout and just above the forest canopy.

Soil flux chambers were installed in four plots within $2 \mathrm{~km}$ of the micrometeorological tower on which air profile samples were taken. The same sites were used for determination of soil NO fluxes [Bakwin et al., this issue (a)]. The dominant soil type is a yellow Oxisol [Keller et al., 1986], consisting of a variable litter layer and a 20 to 30-cm-thick organic-rich horizon underlain by yellowbrown clay. Sites A and T were located on clay soil, within $0.5 \mathrm{~km}$ of each other and the tower base. The other notable soil type in the area was developed on white quartz sand with smaller trees and more open canopy typical of "campina" vegetation. Site $\mathrm{C}$ was located on sandy soil approximately $2 \mathrm{~km}$ from the tower. The soil is characterized by a thick (up to $10 \mathrm{~cm}$ ) mat of interlocking fine roots, underlain by quartz sand mixed with organic matter. A few measurements were made at a transitional site (site B), located between sites A and C.

\section{METHODS}

${ }^{222} \mathrm{Rn}$ was measured using the direct counting technique described by Mathieu et al. [1988]. Samples of air from flux chamber and soil atmosphere measurements (concentrations between 10 and 15,000 atoms $/ \mathrm{cm}^{3}$ ${ }^{222} \mathrm{Rn}$ ) were introduced directly into phosphor-coated counting cells. ${ }^{222} \mathrm{Rn}$ from canopy air samples (less than 10 atoms $/ \mathrm{cm}^{3} 222 \mathrm{Rn}$ ) were preconcentrated on charcoal columns maintained at $-80^{\circ} \mathrm{C}$ by submersion in a dry ice-isopropanol slurry. After evacuation and equilibration to ambient temperature, the columns were heated to $375^{\circ} \mathrm{C}$. Desorbed ${ }^{222} \mathrm{Rn}$ was swept into a counting cell by a stream of $\mathrm{He}$.

${ }^{222} \mathrm{Rn}$ activity was determined by scintillation counting of gross alphas (see Mathieu and Lupton [1972] for counter description, and Mathieu et al. [1988] for calculation of ${ }^{222} \mathrm{Rn}$ activity). The efficiencies of each cell/counter combination (for He and air in each cell), as well as the trapping efficiencies of the activated charcoal columns (>97\%), were determined through the extraction of ${ }^{226} \mathrm{Ra}$ standards at Lamont-Doherty Geological Observatory. Data are tabulated by Trumbore [1988]; a few errors have been corrected here. The average uncertainty for the ${ }^{222} \mathrm{Rn}$ measurements is roughly $10 \%$ of the concentration, predominantly reflecting uncertainty in the determination of cell efficiencies.

\section{${ }^{222}$ Rn Flux From the Soil}

Measurements of the ${ }^{222} \mathrm{Rn}$ flux from soils were made by monitoring the ${ }^{222} \mathrm{Rn}$ activity in the head space of a static enclosure placed over the soil. The majority of the flux measurements were made using collars of Tefloncoated aluminum pipe, $25 \mathrm{~cm}$ diameter, installed in the soil [described by Bakwin et al., this issue (a)]. Two collars were installed at each of the sites. A cover was briefly placed over the pipe to form an enclosure for the duration of the soil flux measurement. We also determined soil emissions using a welded aluminum box (40 $\times 20 \times 10 \mathrm{~cm}, 1 \times \mathrm{w} \times \mathrm{h}$ ), pressed into the soil to approximately $1 \mathrm{~cm}$ depth. Three samples of air (150 to $200 \mathrm{~mL}$ each) were drawn from the the head space in the chamber approximately 30,60 , and $90 \mathrm{~min}$ following closure or emplacement. Each air sample was transferred from a glass syringe into a preevacuated counting cell, which was then filled to atmospheric pressure with ambient air. In three cases where the syringes were not used, the volume of air introduced was determined from the partial pressure of the sample in the preevacuated cell.

The flux of ${ }^{222} \mathrm{Rn}$ from the soil was calculated by linear regression of the observed increase of ${ }^{222} R n$ concentration in the head space. In five of $20 \mathrm{flux}$ determinations the intercept of the least squares line produced improbable activities when extrapolated to the start of the measurement (ambient air had between 0.4 and 10 atom $/ \mathrm{cm}^{3}{ }^{222} \mathrm{Rn}$ ). In all of these cases, one of the three ${ }^{222} \mathrm{Rn}$ measurements was obviously erroneous, and use of the two remaining data points produced an acceptable result.

\section{${ }^{222} \mathrm{Rn}$ in the Soil Atmosphere}

Samples of the soil air space were obtained using 1/8inch-diameter stainless steel sampling tubes, perforated at one end and inserted into the soil to the desired depth. Two sets of tubes were installed at each of the three major sites ( $T, A$, and $C$ ). While the tubes were located close to 
the flux chamber bases, they did not sample the soil air space directly beneath. Syringes were used to draw 20- to $50-\mathrm{mL}$ samples of air from the tubes. Each sample was introduced into a preevacuated counting cell, backfilled to one atmosphere with ambient air, and counted.

\section{${ }^{222} R n$ in Canopy Air}

Accurate measurement of the low ${ }^{222} \mathrm{Rn}$ activities in air required preconcentration of 10 to $20 \mathrm{~L}$ of air on the charcoal columns described above. Sealed nalgene carboys filled with water were used as syphon pumps to pull air through the chilled charcoal columns at rates of 400 to $500 \mathrm{~mL} / \mathrm{min}$, for approximately one-half hour. As water slowly drained from the carboy, the air sample was drawn through the charcoal tube by the suction created in the carboy headspace. An ascarite/drierite trap was placed upstream of the charcoal trap to remove $\mathrm{CO}_{2}$ and water vapor, which might clog the trap. Sampling tubes of polyethylene or teflon were fixed to the micrometeorological tower at heights of $19,27,36$, and $41 \mathrm{~m}$. Additional levels at $0.02,3,6,9$ and $12 \mathrm{~m}$ were sampled using a mast placed in the forest away from the disturbances at the base of the micrometerological tower [Bakwin et al., this issue (a)]. The volume of air drawn through each charcoal column was calculated from the weight of displaced water and the pressure in the head space of the carboy at the end of the measurement ( 2 to 15 mbar less than the ambient atmospheric pressure). Profiles were measured on the evenings of April 22, May 1 , and May 5.

\section{$\mathrm{CO}_{2}$ Flux and Profile Measurements}

The measurements of soil $\mathrm{CO}_{2}$ emissions and profiles of $\mathrm{CO}_{2}$ in the air beneath the forest canopy are described by $F$ an et al. [this issue]. Parallel sampling lines were used for ${ }^{222} \mathrm{Rn}$ and $\mathrm{CO}_{2}$ profile measurements. While the ${ }^{222} \mathrm{Rn}$ profiles are time-averaged samples, the $\mathrm{CO}_{2}$ profiles were made by sampling each level in sequence over an approximately half-hour period. Thus, the $\mathrm{CO}_{2}$ profiles are more likely to reflect short-term variability than the ${ }^{222} \mathrm{Rn}$ profiles. Thirteen nights of continuous $\mathrm{CO}_{2}$ profiles were measured, compared to only eight ${ }^{222} \mathrm{Rn}$ profiles on three nights. We will compare gas exchange rates derived from ${ }^{222} \mathrm{Rn}$ profiles with those from $\mathrm{CO}_{2}$ profiles measured close to the same time. Gas exchange rates from all 13 nights of $\mathrm{CO}_{2}$ profiles will then be averaged to examine variability in exchange through the night.

\section{RESULTS AND DISCUSSION}

\section{Flux of ${ }^{222}$ Rn From the Soil}

Figure 1 shows a histogram of 20 measurements of ${ }^{222}$ Rn soil emissions using the chamber method. Fluxes were determined at different times of day and before, during and after periods of rain, to assess the maximum range of ${ }^{222} \mathrm{Rn}$ emission from the soil. The average of all the soil fluxes is $0.35 \pm 0.05$ atom cm$~_{-2} \mathrm{~s}^{-1}$, where the error term given is the $95 \%$ confidence interval calculated using the "bootstrap" method of Efron and Tibshiani [1986]. The bootstrap method is a computational estimation of the standard error of a

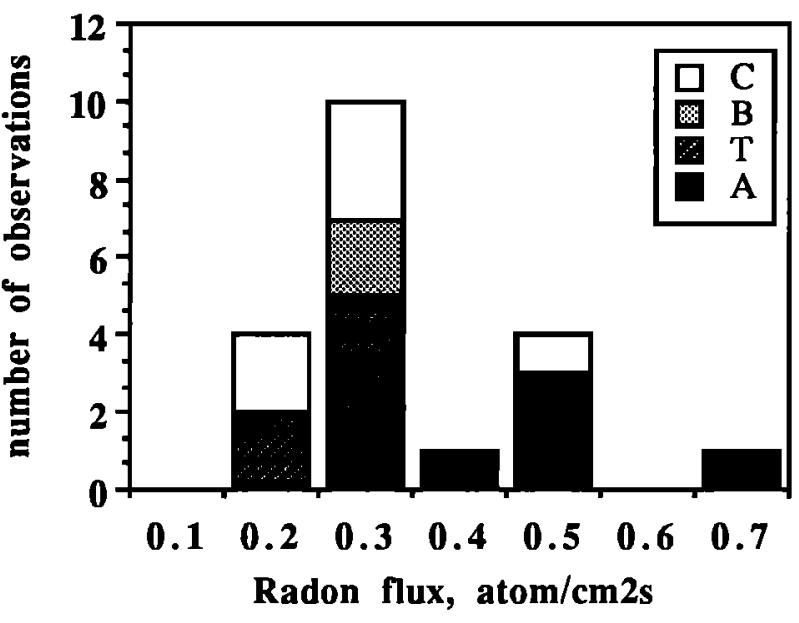

Fig. 1. Histogram of the ${ }^{222} \mathrm{Rn}$ fluxes measured at the four sampling sites identified in the text. The values on the $x$ axis represent the midpoint of an interval, e.g. the category 0.30 contains all fluxes between 0.25 and 0.35 atom $\mathrm{cm}^{-2} \mathrm{~s}^{-1}$.

population which may be nonnormally distributed. The 95\% confidence interval calculated using the Student's $t$ table is similar: \pm 0.06 atom $\mathrm{cm}^{-2} \mathrm{~s}^{-1}$. The average fluxes for the clay and sand soil types did not differ greatly (sites $\mathrm{T}$ and $\mathrm{A}$ averaged $0.38 \pm 0.07$ atom cm $\mathrm{cm}^{-2} \mathrm{~s}^{-1}(\mathrm{~N}=$ 12); site $C$ averaged $0.30 \pm 0.07(N=6)$ ). Since the yellow Oxisol was the spatially dominant soil type near the micrometeorological tower, the average $222 \mathrm{Rn}$ soil emission rate $(S$ in (1)) used in calculations here is $0.38 \pm$ 0.07 atom $\mathrm{cm}^{-2} \mathrm{~s}^{-1}$. This is lower than the global average estimate of 0.75 atom $\mathrm{cm}^{-2} \mathrm{~s}^{-1}$ reported by Wilkening et al., [1974]. To our knowledge, no previous determination of ${ }^{222} \mathrm{Rn}$ emission from Amazon Basin soils has been reported.

\section{Soil Gas Exchange}

Concentrations of ${ }^{222} \mathrm{Rn}$ in the soil atmosphere as a function of depth for sites $\mathrm{T}$ and $\mathrm{A}$ (clay soil) and site $\mathrm{C}$ (sandy soil) are summarized in Figure 2. The clay soil ${ }^{222} \mathrm{Rn}$ concentrations are several times greater than those of the sand soil. The data shown in Figure 2 were taken in conjuction with the soil flux measurements, and thus represent soil conditions on different days and at different times of day. The profiles of ${ }^{222} \mathrm{Rn}$ concentration in the upper $30 \mathrm{~cm}$ of the soil were essentially constant through time. Below this depth there is evidence of periodic trapping and flushing of the soil atmosphere at site $\mathrm{A}$ (Figure 2a). Soil temperature and moisture conditions fluctuated minimally over the day-night cycle and over the course of the ABLE 2B experiment. Thus, observed changes in the soil ${ }^{222} \mathrm{Rn}$ concentration profiles must be the result of other factors which affect gas transport in soils. The profiles from site A show in Figure 2a were taken from different sets of sampling tubes and thus may reflect real differences in the soil structure at this site.

The rate of exchange of gases between the soil atmosphere and overlying air is expressed as an effective diffusivity ( $D_{\text {eff }}$ [Wilkening, 1974; Dörr, 1984; Dörr and Münnich, 1987]). The shape of ${ }^{222} \mathrm{Rn}$ profile in soil air is a function of the rate of ${ }^{222} \mathrm{Rn}$ production and by the 

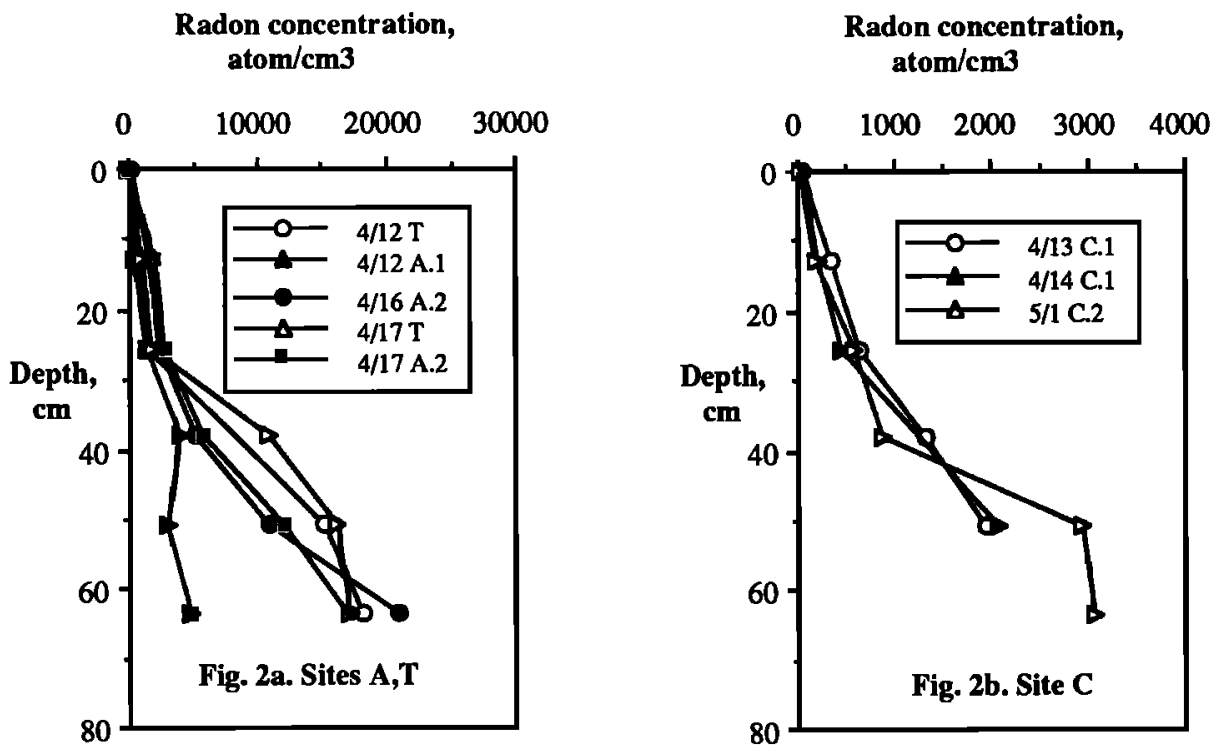

Fig. 2. ${ }^{222} \mathrm{Rn}$ in the soil atmosphere as a function of depth for (a) sites $\mathrm{T}$ and $\mathrm{A}$ (clay soil) and (b) site $\mathrm{C}$ (sand soils, right). Note the difference in concentration scales. Site and date of the measurements are shown. Two sets of gas-sampling probes were installed at each site; the set samples is also identified (e.g. A.1, A.2).

effective diffusivity. In an unstratified soil horizon, neither $D_{\text {eff }}$ nor the production rate would vary with depth, and the ${ }^{222} \mathrm{Rn}$ profile would decrease exponentially from a constant value at depth to essentially zero at the soil surface [Dörr and Münnich, 1987]. The profiles of ${ }^{222} \mathrm{Rn}$ shown in Figure 2 obviously deviate from this ideal case.

We determined ${ }^{222} \mathrm{Rn}$ emanation from the soil by measuring the concentration of ${ }^{222} \mathrm{Rn}$ in secular equilibrium with soil [Trumbore, 1988]. Production of ${ }^{222} \mathrm{Rn}$ by the clay soils (sites $\mathrm{A}$ and $\mathrm{T}$ ) increased with depth, with concentrations at secular equilibrium of several thousand atom $\mathrm{cm}^{-3}$ near the surface, increasing to $15,000-20,000$ atom $\mathrm{cm}^{-3}$ below $25 \mathrm{~cm}$, where values levelled off. ${ }^{222} \mathrm{Rn}$ production in the sand soil increased through the deepest level sampled, and was at all depths less than in the clay soils. The maximum concentration measured for ${ }^{222} \mathrm{Rn}$ in secular equilibrium with sand soil was only 4000 atom $\mathrm{cm}^{-3}$, at $45-$ to $50-\mathrm{cm}$ depth. Since ${ }^{222} \mathrm{Rn}$ fluxes out of the sand and clay soil types were similar, while production of ${ }^{222} \mathrm{Rn}$ was 4-5 times greater in the clay soils, the gas exchange rate must be proportionally greater in the sand soil. A detailed discussion of the derivation of $D_{\mathrm{eff}}$ as a function of depth from ${ }^{222} \mathrm{Rn}$ profiles and ${ }^{222} \mathrm{Rn}$ emanation rates can be found in the work by Trumbore [1988]. To illustrate differences in gas exchange between the two soil types, a simpler calculation of effective diffusivity will be presented here.

An effective diffusivity for radon in the upper $20 \mathrm{~cm}$ of soil can be obtained from the concentration gradient of ${ }^{222} \mathrm{Rn}$ in the soil air space, the flux out of the soil, and the assumption of steady state:

$$
D_{e f f}=\frac{f l u x}{d C /\left.d x\right|_{2 \Rightarrow 0}}
$$

To determine the concentration gradient in the upper 20 $\mathrm{cm}$ of the soil for both soil types, a "steady state" ${ }^{222} \mathrm{Rn}$ profile was calculated for each soil type (clay and sand) as the mean of the available measurements (Figure 2, $a$ and b). A third-order polynomial was fit to the mean profile for each site, and the denominator in (2) calculated as the derivative of this polynomial as the depth approached zero. For both clay and sand soils, this derivative is approximately equal to the slope of a line fit to the concentration versus depth profile in the uppermost 20 $\mathrm{cm}$. For the clay soils, with an average flux of $0.38 \pm$ 0.07 atom $\mathrm{cm}^{-2} \mathrm{~s}^{-1}$, and average concentration gradient of $50 \pm 15$ atom $\mathrm{cm}^{-3}$ per $\mathrm{cm}$ depth, the $D_{\text {eff }}$ derived from (2) is $0.008 \pm 0.004 \mathrm{~cm}^{2} \mathrm{~s}^{-1}$. The mean effective diffusivity computed for the sand soil (flux, $0.30 \pm 0.07$ atom $\mathrm{cm}^{-2} \mathrm{~s}^{-1}$, gradient, $9 \pm 1$ atom cm $\mathrm{cm}^{-3}$ per $\mathrm{cm}$ depth) was 4 times higher, $0.033 \pm 0.030 \mathrm{~cm}^{2} \mathrm{~s}^{-1}$, consistent with the inference based on emanation rates

The small difference in average ${ }^{222} \mathrm{Rn}$ emission between the two soil types reflects combined differences in ${ }^{222} \mathrm{Rn}$ production (greater in clay than sand [Trumbore, 1988]) and soil atmosphere exchange rate (greater in sand than clay). NO fluxes from the sand soil averaged 4 times those from the clay soils [Bakwin et al., this issue (a)]. The ${ }^{222} \mathrm{Rn}$ results support the idea, advanced by Bakwin et al. [this issue (a)], that higher NO flux from the sand soil may be attributed to more rapid ventilation of the soil atmosphere.

\section{Rn Profiles and Canopy Ventilation}

The development of a nocturnal inversion over the forest provides the best chance to observe measurable accumulations of ${ }^{222} \mathrm{Rn}$ and $\mathrm{CO}_{2}$ in the canopy layer. The flushing of air within a forest canopy may occur sporadically, potentially compromising attempts to calculate flux density from concentration gradients 
[Denmead and Bradley, 1985; Shaw, 1985]. 222 Rn profiles time-averaged over a period of one-half hour, smooth out such short-term variability.

${ }^{222} \mathrm{Rn}$ and $\mathrm{CO}_{2}$ profiles for the three nights when ${ }^{222} \mathrm{Rn}$ profiles were obtained (April 22, May 1, and May 5,1987 ) are shown in Figures 3, 4, and 5. A common feature in all three sets of profiles is a steep gradient in concentration for both gases observed in the 0 - to $3-\mathrm{m}$ interval. Above $3 \mathrm{~m}$, the air column is relatively well mixed. ${ }^{222} \mathrm{Rn}$ and $\mathrm{CO}_{2}$ both accumulate in the canopy layer with time after about 1600 . Changes in accumulated $\mathrm{CO}_{2}$ and ${ }^{222} \mathrm{Rn}$ generally correspond, although the $\mathrm{CO}_{2}$ profiles may reflect patchiness averaged out in the radon profiles, and radon profiles consist of fewer levels. In the May 5 experiment (Figures $5 a$ and $5 b$ ), a flushing event between 2130 and 2400 reduced the inventory of these gases to near afternoon levels.

The steep concentration gradients observed in the 0 - to $3-\mathrm{m}$ layer of the atmosphere indicate that this boundary is a major resistance to vertical transport of gases from soils. The resistance to vertical exchange in this layer $(R$, $\mathrm{s} \mathrm{cm}^{-1}$ ), may be derived from the assumption that the input of ${ }^{222} \mathrm{Rn}$ or $\mathrm{CO}_{2}$ to this layer from soil emission equals the loss by upward mixing during the period of profile measurement (one-half hour). The exchange rate, $k(=1 / R)$ equals the soil emission rate $(S)$ divided by the concentration difference:

$$
k=\frac{1}{R_{i}}=\frac{S_{i}}{C_{\mathrm{i}}^{0 \mathrm{~m}}-C_{i}^{3 \mathrm{~m}}}
$$

The soil emission rates $(S)$ for ${ }^{222} \mathrm{Rn}$ and $\mathrm{CO}_{2}$ are 0.38 \pm 0.07 atom $\mathrm{cm}^{-2} \mathrm{~s}^{-1}$ and $30 \pm 3 \times 10^{13}$ molecules $\mathrm{cm}^{-}$ $\mathbf{2}^{-1}$ [Fan et al., this issue], respectively. Aerodynamic resistances for $i={ }^{222} \mathrm{Rn}$ and $\mathrm{CO}_{2}$, compared in Figure 6, range from 1.7 to $18.5 \mathrm{~s} \mathrm{~cm}^{-1}$, with highest values in the late afternoon. The correlation between $R$ calculated from ${ }^{222} \mathrm{Rn}$ and $\mathrm{CO}_{2}$ in the $0-$ to $3-\mathrm{m}$ layer $\left(r^{2}=0.96\right)$ indicates that uptake and emission of $\mathrm{CO}_{2}$ by vegetation in that layer does not significantly modify the soil flux. The resistances obtained from these two gases can be used to calculate the proportion of nocturnal $\mathrm{O}_{3}$ deposition occuring at the ground level relative to the canopy, as discussed by $F$ an et al. [this issue], and to estimate net fluxes from the soil of other reactive trace gases, such as NO [Bakwin et al., this issue (a)]. The good correspondance between values of $R$ for ${ }^{222} \mathrm{Rn}$ and $\mathrm{CO}_{2}$ suggests that soil emission rates are accurate to $\pm 25 \%$ or better.

In order to use (1) to calculate exchange for the air from the entire $41 \mathrm{~m}$ layer, the role of emission and destruction of ${ }^{222} \mathrm{Rn}$ within the forest canopy must be assessed. Radon present in the soil atmosphere can dissolve in soil water, be taken up by plant roots, and transpired directly into the canopy air space, bypassing soil gas exchange. The magnitude of this flux has been a subject of some controversy [Pearson and Jones, 1966; Rolf and Mattsson, 1970]. In order to put an upper bound on ${ }^{222} \mathrm{Rn}$ flux through the vegetation we may assume transpiration of $2 \mathrm{~m}$ of water per year (all rainfall), equilibrated with a soil atmosphere with ${ }^{222} \mathbf{R} \mathbf{n}$ concentration of 15,000 atom $\mathrm{cm}^{-3}$ (the maximum observed soil atmosphere ${ }^{222} \mathrm{Rn}$ concentration). We assume forest vegetation mainly transports gases from

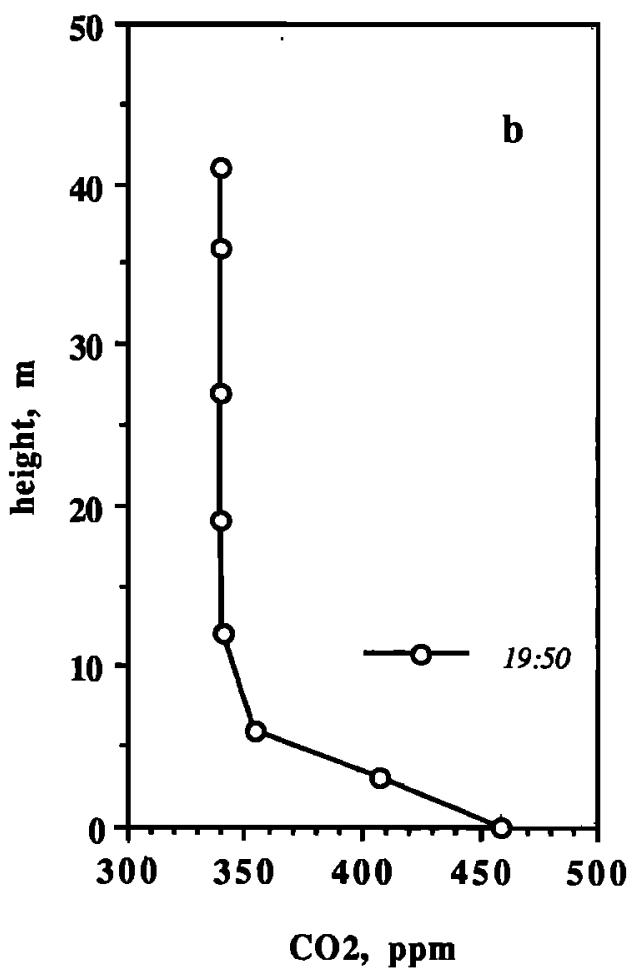

Fig. 3. Profiles for (a) ${ }^{222} \mathrm{Rn}$ and (b) $\mathrm{CO}_{2}$ in the canopy air measured on April 22 . The times assigned to the profiles represent the midpoint of the sampling period. The $10 \%$ error bars are shown for the ${ }^{222} \mathrm{Rn}$ data. 

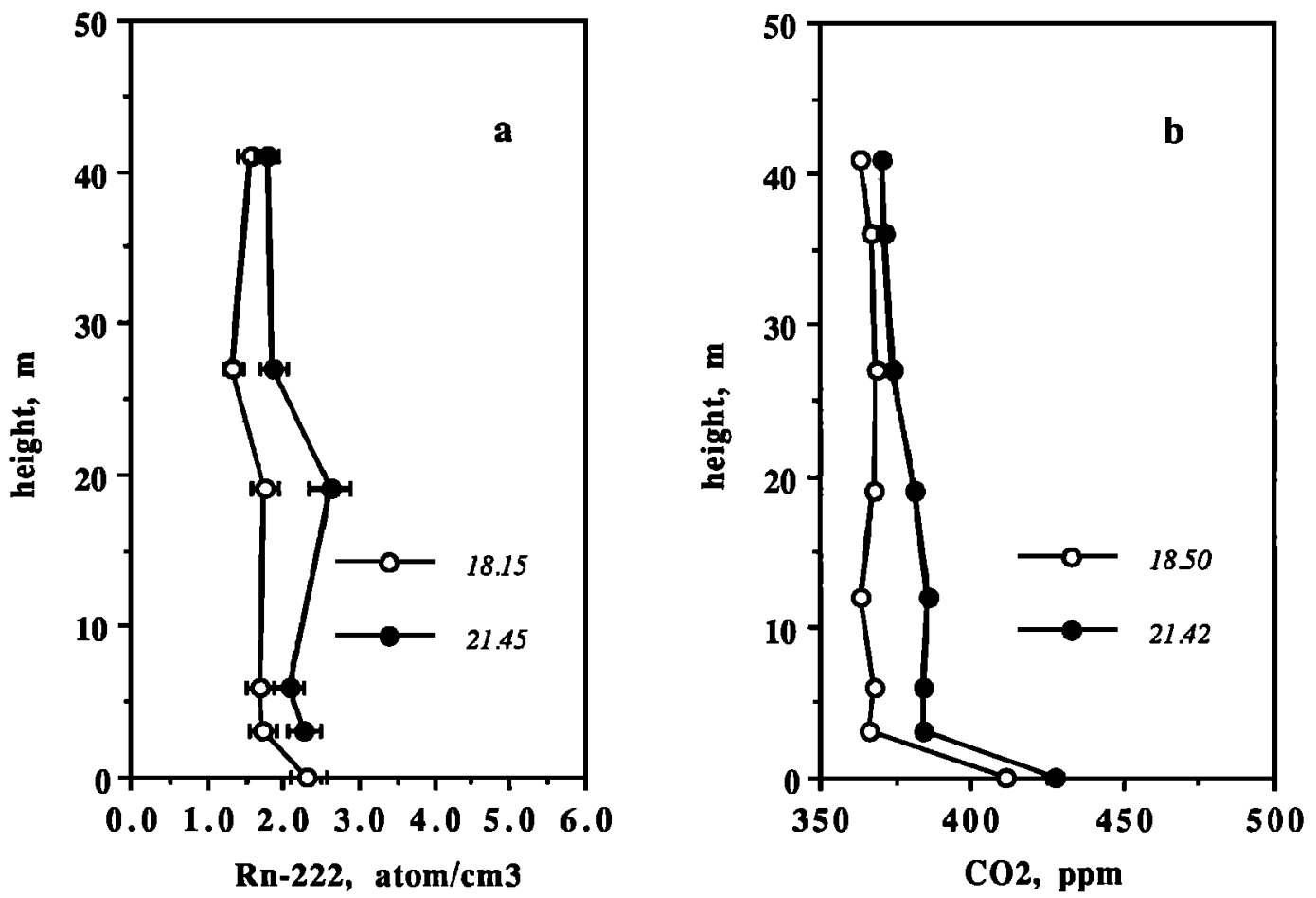

Fig. 4. Profiles for (a) ${ }^{222} \mathrm{Rn}$ and (b) $\mathrm{CO}_{2}$ in the canopy air measured on May 1 .
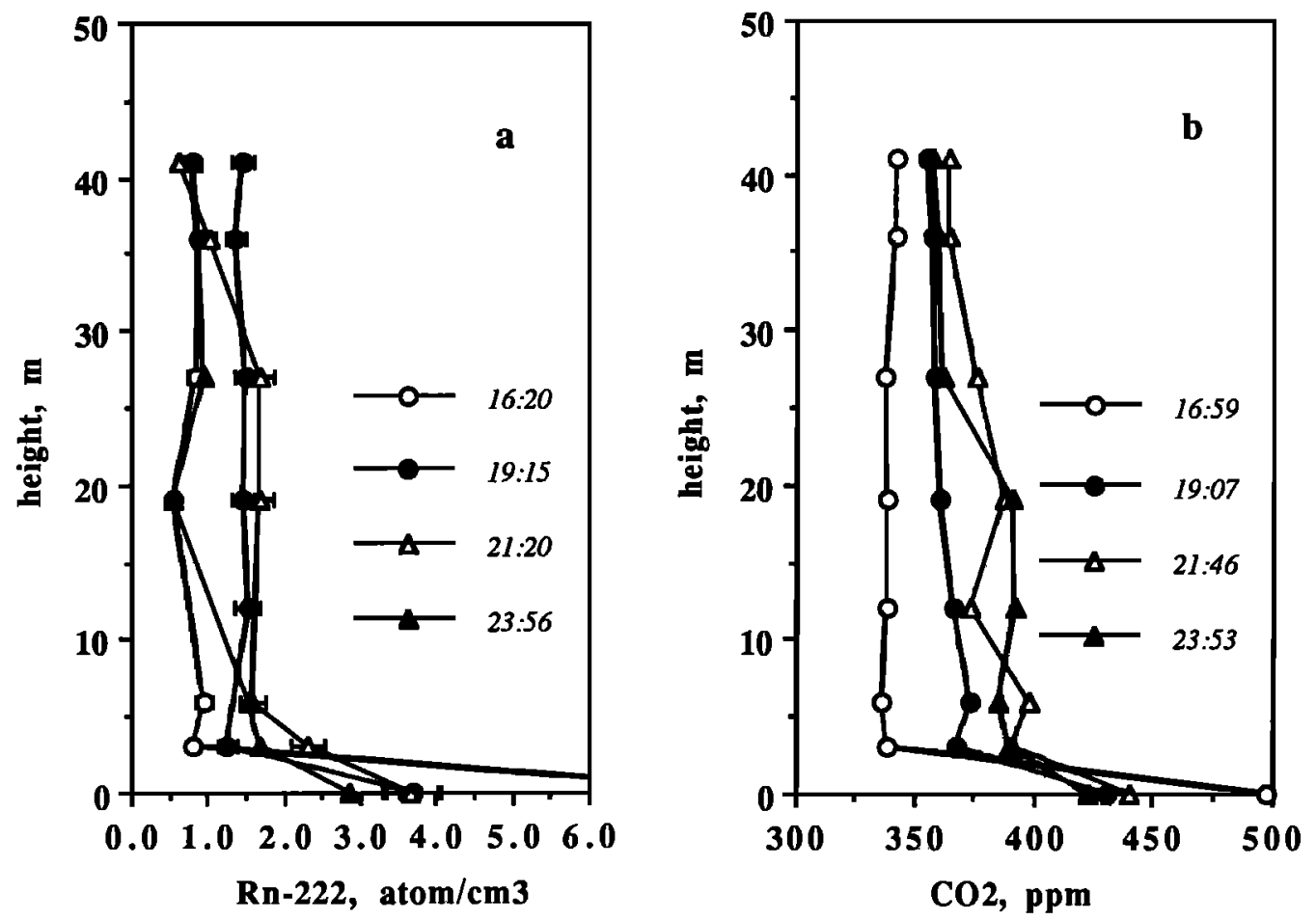

Fig. 5. Profiles for (a) ${ }^{222} \mathrm{Rn}$ and (b) $\mathrm{CO}_{2}$ in the canopy air measured on May 5 .

roots to canopy in solution [Armstrong, 1979]. We calculate a maximum average flux of ${ }^{222} \mathrm{Rn}$ from canopy vegetation of 0.02 atom $\mathrm{cm}^{-2} \mathrm{~s}^{-1}$, roughly $5 \%$ of the observed soil flux. As transpiration is only an important process during daylight hours, ${ }^{222} \mathrm{Rn}$ emissions from plants may be neglected entirely during our nocturnal sampling.

The loss of ${ }^{222} \mathrm{Rn}$ due to radioactive decay in the subcanopy layer is also small compared to soil emission. A column of air $41 \mathrm{~m}$ high with a crossectional area of 1 


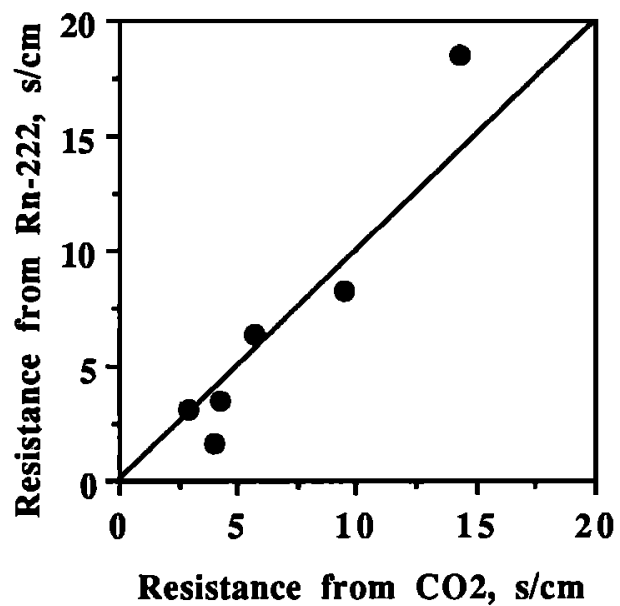

Fig. 6. Comparison of aerodynamic resistances for the 0 - to 3-m layer from ${ }^{222} \mathrm{Rn}$ and $\mathrm{CO}_{2}$. Aerodynamic resistance is calculated as the concentration difference between 0 and $3 \mathrm{~m}$ divided by the soil emission rate, using 0.38 atom $\mathrm{cm}^{-2} \mathrm{~s}^{-1}$ for ${ }^{222} \mathrm{Rn}$, and $30 \times 10^{13}$ molecule $\mathrm{cm}^{-2} \mathrm{~s}^{-1}$ for $\mathrm{CO}_{2}$ \{Fan et al., this issue]. A $1: 1$ line is shown for comparison.

$\mathrm{cm}^{2}$, with average radon concentration of 2 atom $\mathrm{cm}^{-3}$, will decay at a rate of 0.009 atom cm-2 $\mathrm{s}^{-1}, 2$ to $3 \%$ of the-soil source. Thus the change in ${ }^{222} \mathrm{Rn}$ inventory in the canopy air, determined by pairwise comparison of integrated vertical profiles, is regulated by a balance between the soil source, ventilation, and storage. Terms involving production $(P)$ and loss $(L)$ can be neglected, and (1) is rewritten:

$$
k=\frac{1}{R}=\frac{h\left(\overline{d C_{R n}} / d t\right)-S}{\left[\overline{C_{R n}}-C_{R_{n}}^{t}\right]}
$$

where $h\left(\overline{d C_{R n}} d d t\right)$ is the change in inventory of the the 0 - to 41-m layer obtained by pairwise comparison of sequential profiles, and $\overline{C_{R n}}-C_{R_{n}}^{t}$ is the difference between the average ${ }^{222} \mathrm{Rn}$ concentration in the 0 - to $41-\mathrm{m}$ canopy layer over the entire period and the ${ }^{222} \mathrm{Rn}$ concentration of the air above the canopy layer. $C_{R n}^{f}$ was assigned the value of ${ }^{222} \mathrm{Rn}$ oberved at $41 \mathrm{~m}$ in the earliest profile measured on each day. Gas exchange coefficients $(k)$ computed from both ${ }^{222} \mathrm{Rn}$ and $\mathrm{CO}_{2}$ profiles (shown in Figures 3, 4, and 5) are compared in Table 1 . The calculation of $k$ from $\mathrm{CO}_{2}$ profiles assumed no production or destruction of $\mathrm{CO}_{2}$ in the canopy layer, and the $\mathrm{CO}_{2}$ concentration in the air ventilating the canopy layer was assigned the $41 \mathrm{~m}$ value for the profile measured closest to 1700 . The estimated uncertainties in $k$ are large for both gases. For ${ }^{222} \mathrm{Rn}$, the uncertainty primarily reflects difficulty in estimating the inventory of ${ }^{222} \mathrm{Rn}$ in the sub-canopy layer from measurements made at five or six discrete levels. This could be improved with increased sampling capability. Uncertainties in $k$ computed from $\mathrm{CO}_{2}$ profiles reflect the smaller dynamic range for $\mathrm{CO}_{2}$ in the canopy layer. An additional uncertainty arises from the fact that the height of the boundary layer is not constant, as shown by the changes in the concentration of ${ }^{222} \mathrm{Rn}$ and $\mathrm{CO}_{2}$ at the $41-\mathrm{m}$ point in Figures 3 through
TABLE 1. Comparison of Gas Exchange Rates Calculated From Profiles of ${ }^{222} \mathrm{Rn}$ and $\mathrm{CO}_{2}$

\begin{tabular}{lccc}
\hline Date & $k_{\mathrm{Rn}, \mathrm{cm} \mathrm{s}^{-1}}$ & $k_{\mathrm{CO} 2, \mathrm{~cm} \mathrm{~s}^{-1}}$ & $P_{\mathrm{CO} 2}$ \\
\hline April 22 & $0.11 \pm 0.09$ & $\mathrm{ND}$ & $\mathrm{ND}$ \\
& & & \\
May 1 & $0.25 \pm 0.13$ & $0.17 \pm 0.15$ & $3.0 \pm 7.5$ \\
& & & \\
May 5 & $0.35 \pm 0.14$ & $0.05 \pm 0.60$ & $3.8 \pm 8.6$ \\
& $0.35 \pm 0.15$ & $0.18 \pm 0.10$ & $10.0 \pm 11.8$ \\
& $0.60 \pm 0.16$ & $0.42 \pm 0.11$ & $14.8 \pm 16.2^{*}$ \\
Mean & $0.33 \pm 0.15$ & $0.20 \pm 0.36$ & $7.9 \pm 13.3$ \\
& & & $5.6 \pm 11.6^{* *}$ \\
\hline
\end{tabular}

The calculation of $k$ is described in the text. Results are given in chronological order. Exchange rates calculated from ${ }^{222} \mathrm{Rn}$ profiles are consistently greater than those calculated from $\mathrm{CO}_{2}$ data, suggesting production of in the canopy layer. The rate of $\mathrm{CO}_{2}$ production, assuming the rate of canopy ventilation is calculated from $R$ is correct, is given in the column labelled $\mathrm{PCO}_{\mathrm{CO}}$ (in molecules $\mathrm{cm}^{-2} \mathrm{~s}^{-1}$ ). Means are calculated with and without $\left({ }^{* *}\right)$ the last determination on May $5\left(^{*}\right)$. The soil $\mathrm{CO}_{2}$ flux (from $\mathrm{Fan}$ et al., this issue) is 30 $\pm 3 \times 10^{13}$ molecules $\mathrm{cm}^{-2} \mathrm{~s}^{-1}$.

5. Since it was not possible to sample to heights greater than $41 \mathrm{~m}$, we assume that the air periodically flushing the subcanopy layer remains close to the concentration of air observed at $41 \mathrm{~m}$ in the late afternoon, before development of the inversion layer.

For each pair of profiles used to compute entries in Table 1, the gas exchange rate $(k)$ calculated from $\mathrm{CO}_{2}$ profiles is less than the corresponding $k$ calculated from ${ }^{222} \mathrm{Rn}$. This difference reflects a net source of $\mathrm{CO}_{2}$ in the above-ground vegetation at night from respiration. The amount of $\mathrm{CO}_{2}$ production in the canopy can be estimated by adopting the exchange coefficients from ${ }^{222} \mathrm{Rn}$ and by solving for $P-L$ in (1). In this case, $L$ represents uptake by photosynthesis, zero at night. The production $(P)$ of $\mathrm{CO}_{2}$ in the above-ground vegetation for the pairwise profile comparisons is computed in the last two columns of Table 1 . The lowest value, representing about $10 \%$ of the soil $\mathrm{CO}_{2}$ flux [Fan et al., this issue], occurs at 1600 on May 5, when photosynthesis was still occuring. The highest value reflects, in part, error introduced by the sparse sampling of the radon profile; from Figures $5 a$ and $5 b$ it can be seen that a maximum in $\mathrm{CO}_{2}$ concentration occurred at $12 \mathrm{~m}$, a level which was not sampled for ${ }^{222} \mathrm{Rn}$. The average of all four values gives an estimate of the proportion of $\mathrm{CO}_{2}$ added to the subcanopy layer by canopy respiration, $26 \%$ of the soil flux. Excluding the last profile on May 5, the average of nighttime values is $19 \pm 38 \%$ of the soil flux, consistent with the estimate of $12 \%$ based on the eddy correlation flux measurement for $\mathrm{CO}_{2}$ [Fan et al., this issue]. The large uncertainty in this estimate could be improved in a more comprehensive program of ${ }^{222} \mathrm{Rn}$ profile measurements. 
TABLE 2. Exchange Rates $\left(k, \mathrm{~cm} \mathrm{~s}^{-1}\right)$ and Resistances $(=1 / k)$ averaged in 2 -Hour Intervals Through the Night From 13 Nights of $\mathrm{CO}_{2}$ Profiles.

\begin{tabular}{lccl}
\hline Interval & $\begin{array}{c}k, \text { (std. dev.) } \\
\mathrm{cm} \mathrm{s}^{-1}\end{array}$ & $\begin{array}{c}R, \\
\mathrm{~s} \mathrm{~cm}^{-1}\end{array}$ & $\begin{array}{l}\text { FT, } \\
\text { hours }\end{array}$ \\
\hline $17.00-19.00$ & $1.19(3.0)$ & 0.8 & 1.0 \\
$19.00-21.00$ & $0.27(0.4)$ & 3.7 & 4.2 \\
$21.00-23.00$ & $0.19(0.4)$ & 5.3 & 6.0 \\
$23.00-01.00$ & $0.22(0.6)$ & 4.6 & 5.2 \\
$01.00-03.00$ & $0.20(0.5)$ & 5.0 & 5.7 \\
$03.00-05.00$ & $0.20(0.4)$ & 4.9 & 5.6 \\
$05.00-07.00$ & $0.18(0.4)$ & 5.6 & 6.4 \\
Mean & & & \\
$(19.00-07.00)$ & $0.21(0.4)$ & 4.8 & 5.5 \\
\hline
\end{tabular}

Calculations of $k$ were made as for Table 1, by pairwise comparison of sequential profiles. No correction was made for $\mathrm{CO}_{2}$ production in the forest canopy. The flushing time (FT, in hours) for the air column to $41 \mathrm{~m}$ is calculated.

While information on canopy ventilation from ${ }^{222} \mathrm{Rn}$ measurements is only available for three nights, $\mathrm{CO}_{2}$ profiles were measured continuously for 13 nights. In addition $\mathrm{CO}_{2}$ profiles cover the entire nocturnal period, while ${ }^{222} \mathrm{Rn}$ profiles do not extend past midnight. Table 2 summarizes the gas exchange rates and aerodynamic resistances calculated using (4), and by averaging all of the 13 nights of continuous $\mathrm{CO}_{2}$ profiles grouped in two hour intervals [Fan et al., this issue]. The exchange rates calculated in Table 2 neglect $\mathrm{CO}_{2}$ production in the canopy vegetation. The average ventilation rate from all $\mathrm{CO}_{2}$ measurements $\left(0.21 \pm 0.40 \mathrm{~cm} \mathrm{~s}^{-1}\right)$ is roughly $60 \%$ of the average ventilation rate calculated from ${ }^{222} \mathrm{Rn}$ profiles $\left(0.33 \pm 0.15 \mathrm{~cm} \mathrm{~s}^{-1}\right.$; Table 1$)$, apparently reflecting $\mathrm{CO}_{2}$ production in the canopy. Both estimates are in harmony with independent measurements of exchange using micrometeorological methods [Fitzjarrald et al., this issue; Fan et al., this issue]. The time required to flush the $41 \mathrm{~m}$ canopy averages 5.5 hours during the night (3.4 hours using the average exchange rate from ${ }^{222} \mathrm{Rn}$ ), and shows no significant variation from hour to hour. This steady behavior represents the influence of averaging, since individual nights showed marked periods of stagnation interrupted by abrupt ventilation events. These results can help define fluxes of other gases measured during ABLE 2B, for example $\mathrm{O}_{3}[F$ an et al., this issue], NO and $\mathrm{NO}_{\mathrm{y}}$ [Bakwin et al., this issue $(a),(b)]$.

\section{CONCLUSIONS}

The greatest resistance to transfer of trace gases from the soil to the atmosphere lies in the soil air space. The major resistance to vertical transfer above the soil-air interface is in the 0- to 3-m layer, where steep gradients in trace gas concentrations occur $\left(R=1.6\right.$ to $\left.18 \mathrm{~s} \mathrm{~cm}^{-1}\right)$. The resistance to exchange with air from the entire $41 \mathrm{~m}$ layer below the canopy averaged $4.8 \mathrm{~s} \mathrm{~cm}^{-1}$ during 13 nights of $\mathrm{CO}_{2}$ profiles. The calculated average time to flush the layer below $41 \mathrm{~m}$ is 5.5 hours, which implies that significant exchange occurs despite nocturnal stratification.

Independent measurements of physical transport are important for the interpretation of trace gas profiles in soil and canopy air. Measurements of ${ }^{222} \mathrm{Rn}$ provide an inexpensive method with which to characterize exchange processes, in sites where micrometeorological measurements cannot be made. The use of rates of exchange obtained from ${ }^{222} \mathrm{Rn}$ in the interpretation of trace gas profiles measured during ABLE 2B is illustrated in this paper, in Bakwin et al. [this issue (a),(b)] and Fan et al. , [this isse]. Future efforts to measure fluxes of reactive trace gases from ecosystems would benefit from an expanded program to measure ${ }^{222} \mathrm{Rn}$.

Acknowledgments. This work was supported by NASA grant NAG 1-55 to Harvard University. Equipment for the ${ }^{222} \mathrm{Rn}$ measurements was kindly lent by P. Biscaye, G. Mathieu, W. Smethie, and K. Ellins of Lamont-Doherty Geological Observatory. We thank G. Mathieu for many helpful discussions. S.-M. Fan and P. Bakwin assisted in the field measurements. LDGO contribution 4606.

\section{REFERENCES}

Armstrong, W., Aeration in higher plants, Ann. Rev. Botanical Res., 7, 225-332, 1979.

Bakwin, P. S., S. C. Wofsy, S.-M. Fan, M. Keller, S. Trumbore, and J. M. da Costa, Emission of nitric oxide (NO) from tropical forest soils and exchange of NO between the forest canopy and atmospheric boundary layers, $J$. Geophys. Res., this issue (a).

Bakwin, P. S., S. C. Wofsy, S.-M. Fan, Measurements of reactive nitrogen oxides $\left(\mathrm{NO}_{\mathrm{y}}\right)$ within and above a tropical forest canopy in the wet season, J. Geophys. Res., this issue $(b)$.

Clements, W. E., and M. H. Wilkening, Atmospheric pressure effects and ${ }^{222} \mathrm{Rn}$ transport across the earth-air interface, $J$. Geophys. Res., 79, 5025-5029, 1974.

Denmead, O. T., and E. F. Bradley, Flux-gradient relationships in a forest canopy, in The Forest-Atmosphere Interaction, edited by B. A. Hutchinson and B. B. Hicks, pp. 421- 442, D. Reidel, Hingham, Mass., 1985.

Dörr, H., Die Untersuchung des Gas und Wasserhaushalts in der Ungesattingten Bodenzone mit Hilfe von $\mathrm{CO}_{2}$ und ${ }^{222} \mathrm{Rn}$ Messungen, Ph.D. dissert., Univ. Heidelberg, Federal Republic of Germany, 1984.

Dörr, H., and K. O. Münnich, Annual variation in soil respiration, Tellus, 39B, 114-121, 1987.

Efron, B., and R. Tibshiani, Bootstrap methods for standard errors, confidence intervals, and other measures of statistical accuracy, Statist. Sci., 1, 54-77, 1986.

Fan, S.-M., S. C. Wofsy, P. S. Bakwin, and D. Jacob, Atmosphere-biosphere exchange of $\mathrm{CO}_{2}$ and $\mathrm{O}_{3}$ in the central Amazon Forest, J. Geophys. Res., this issue.

Fitzjarrald , D. R., K. E. Moore, O. Cabral, J. Scolar, A. O. Manzi, and L. C. de Abreau Sá, Daytime turbulent exchange between the Amazon forest and the atmosphere, $J$. Geophys. Res., this issue.

Jacob, D. J., and S. C. Wofsy, Budgets of reactive nitrogen, hydrocarbons, and ozone over the Amazon forest during the wet season, J. Geophys. Res., this issue.

Kaplan, W. A., S. C. Wofsy, M. Keller, and J. M. da Costa, Emission of $\mathrm{NO}$ and deposition of $\mathrm{O}_{3}$ in a tropical forest ecosystem,J. Geophys. Res., 93, 1389-1395, 1988.

Keller, M., W. A. Kaplan, and S. C. Wofsy, Emissions of $\mathrm{N}_{2} \mathrm{O}$, 
$\mathrm{CH}_{4}$, and $\mathrm{CO}_{2}$ from tropical forest soils, J. Geophys. Res., 91, 11,791-11,802, 1986.

Mathieu, G. G., and R. A. Lupton, Radon experimental technique of analysis, annual progress report, Atomic Energy Commission, Washington, D. C., 1972.

Mathieu, G. G., P. E. Biscaye, R. A. Lupton and D. E. Hammond, System for measurement of ${ }^{222} \mathrm{Rn}$ at low levels in natural waters, Health Phys., 55, 989-992, 1988.

Mattsson, R., Seasonal variability of short-lived radon progeny, ${ }^{210} \mathrm{~Pb}$ and ${ }^{210} \mathrm{Po}$, in ground level air in Finland, $J$. Geophys. Res., 75, 1741-1744, 1970.

Pearson, J. E., and G. E. Jones, Soil concentrations of "emanating Ra-226" and the emanation of $\mathrm{Rn}-222$ by plants, Tellus, 18, 655-661, 1966.

Rasmussen, R. A., and M. A. Khalil, Isoprene over the Amazon Basin, J. Geophys. Res., 93, 1417-1421, 1988.

Shaw, R. H., On the diffusive and dispersive fluxes in forest canopies, in The Forest-Atmosphere Interaction, edited by B. A. Hutchinson and B. B. Hicks, pp. 407-419, D. Reidel, Hingham, Mass., 1985.

Tanner, A. B., Radon migration in the ground: A review, in The Natural Radiation Environment, pp. 161-190, University of Chicago Press, Chicago, Il., 1964.

Trumbore, S. E., Carbon cycling and gas exchange in soils, Ph.D. thesis, 194 pp.,Columbia University, New York, 1988.

Wilkening, M. H., Radon transport processes below the earth's surface, in The Natural Radiation Environment III, pp. 90-104, National Technical Information Service, Springfield, Va., 1980.

Wilkening, M. H., W.E. Clements, and D. Stanley, Radon-222 flux measurements in widely separated regions, in The Natural Radiation Environment II, pp. 717-730, National Technical Information Service, Springfield, Va., 1972.

Zimmerman, P. R., J. P. Greenberg and C. E. Westberg, Measurements of atmospheric hydrocarbons and biogenic emission fluxes in the Amazon boundary layers, $J$. Geophys. Res., 93, 1407-1416, 1988.

J. M. da Costa, Universidad Federal de Vicosa, Departament Engenharea Agricola 36576, Minas Gerais, Brazil.

M. Keller, National Center for Atmospheric Research, P. O. Box 3000, Boulder, CO 80307.

S. E. Trumbore, Center for Accelerator Mass Spectrometry, Lawrence Livermore National Laboratory, L-397, P.O. Box 808, Livermore, CA 94550.

S. C. Wofsy, Department of Earth and Planetary Sciences, Division of Applied Sciences, Harvard University, Cambridge, MA 02138.

(Received November 28, 1989; revised March 20, 1990; accepted March 28, 1990.) 